\title{
Complementary roles of KCa3.1 channels and $\beta 1$-integrin during alveolar epithelial repair
}

\author{
Alban Girault ${ }^{1,2}$, Jasmine Chebli ${ }^{1,2}$, Anik Privé ${ }^{1}$, Nguyen Thu Ngan Trinh ${ }^{1,2}$, Emilie Maillé ${ }^{1}$, Ryszard Grygorczyk ${ }^{1,2}$ \\ and Emmanuelle Brochiero ${ }^{1,2^{*}}$
}

\begin{abstract}
Background: Extensive alveolar epithelial injury and remodelling is a common feature of acute lung injury and acute respiratory distress syndrome (ARDS) and it has been established that epithelial regeneration, and secondary lung oedema resorption, is crucial for ARDS resolution. Much evidence indicates that $\mathrm{K}^{+}$channels are regulating epithelial repair processes; however, involvement of the KCa3.1 channels in alveolar repair has never been investigated before.

Results: Wound-healing assays demonstrated that the repair rates were increased in primary rat alveolar cell monolayers grown on a fibronectin matrix compared to non-coated supports, whereas an anti- $\beta 1$-integrin antibody reduced it. KCa3.1 inhibition/silencing impaired the fibronectin-stimulated wound-healing rates, as well as cell migration and proliferation, but had no effect in the absence of coating. We then evaluated a putative relationship between KCa3.1 channel and the migratory machinery protein $\beta 1$-integrin, which is activated by fibronectin. Co-immunoprecipitation and immunofluorescence experiments indicated a link between the two proteins and revealed their cellular co-distribution. In addition, we demonstrated that KCa3.1 channel and $\beta 1$-integrin membrane expressions were increased on a fibronectin matrix. We also showed increased intracellular calcium concentrations as well as enhanced expression of TRPC4, a voltage-independent calcium channel belonging to the large TRP channel family, on a fibronectin matrix. Finally, wound-healing assays showed additive effects of KCa3.1 and TRPC4 inhibitors on alveolar epithelial repair.
\end{abstract}

Conclusion: Taken together, our data demonstrate for the first time complementary roles of KCa3.1 and TRPC4 channels with extracellular matrix and $\beta 1$-integrin in the regulation of alveolar repair processes.

\section{Background}

Extensive damage and remodelling of the alveolar epithelium occur in various lung pathologies, including acute lung injury (ALI) and its more severe form, acute respiratory distress syndrome (ARDS) [1-3]. Alveolar regeneration, which is crucial to restore alveolar epithelial integrity and function, is thus a critical component of ARDS resolution and patient recovery $[1,2,4]$.

After damage, several cellular events are engaged in an attempt to restore alveolar integrity, including changes in cell-matrix adhesion through the action of matrix metalloproteinases and integrin receptors, cytoskeleton

\footnotetext{
* Correspondence: emmanuelle.brochiero@umontreal.ca

${ }^{1}$ Centre de recherche du Centre hospitalier de I'Université de Montréal (CRCHUM), Tour Viger, 900 rue Saint-Denis, Montréal, Québec H2X0A9, Canada

²Département de médecine, Université de Montréal, CP6128, Succursale Centre-ville, Montréal, Québec H3C3J7, Canada
}

reorganization, cell spreading and migration, as well as cell proliferation and differentiation [5]. These complex processes integrate multiple mechanisms and proteins, which are regulated by various components such as growth factors, growth factor receptors and downstream signalling pathways [5-7]. Integrins play an active role in epithelial repair, not only by creating a link between the ECM and cell cytoskeleton but also by interacting with proteins involved in cell migration and proliferation, including growth factor receptors, protein kinases as well as ion channels [811]. $\beta 1$-integrin, for example, has been shown to regulate alveolar type II (ATII) cell migration on fibronectin matrix [12]. Moreover, increased levels of fibronectin and collagen have been detected in lung tissues from patients with ARDS [13]. 
Increasing evidence also indicates a function of potassium $\left(\mathrm{K}^{+}\right)$channels in the regulation of epithelial repair processes [14]. More precisely, silencing or inhibition of different types of $\mathrm{K}^{+}$channels has been reported to decrease epithelial cell proliferation [15-18], motility $[15,16,19-23]$ and differentiation [20], as well as epithelial wound repair $[15,16,24-26]$. Our data on primary rat ATII cells previously highlighted an involvement of two types of $\mathrm{K}^{+}$channels, i.e. KvLQT1 and $\mathrm{K}_{\mathrm{ATP}}$ in the control of cell proliferation, motility and repair [15]. A role for KCa3.1 channels in airway ion transport [27, 28], as well as repair processes of several epithelial tissues [16, 22, 29] has also been established; however, the contribution of this channel in alveolar repair has not been explored before.

The mechanisms whereby $\mathrm{K}^{+}$channels control epithelial repair processes may be multiple, including changes in membrane potential, cell volume and shape, $\left[\mathrm{Ca}^{2+}\right]_{\mathrm{i}}$ and various signalling pathways (for review see [14]). In addition, several reports indicated that different types of $\mathrm{K}^{+}$channels (e.g. BKCa, Kv1.3, hERG, GIRK, Kir4.2) could also directly interact with migratory machinery proteins, such as $\beta 1$-integrins [30-33]. However, to the best of our knowledge, a relationship between the KCa3.1 and $\beta 1$-integrin in epithelial cells has never been investigated before.

Based on these data, we postulated that $\mathrm{KCa} 3.1$ and $\beta 1$ integrin play a complementary role during alveolar epithelial repair. We thus evaluated the roles of extracellular fibronectin matrix, $\beta 1$-integrin and $\mathrm{KCa} 3.1$ channels in alveolar repair processes, especially cell migration, proliferation and wound healing after mechanical injury. Finally, the regulation and complementary function of TRPC4 $\mathrm{Ca}^{2}$ ${ }^{+}$channels were explored.

\section{Methods}

\section{Alveolar epithelial type II cell isolation and primary culture}

Alveolar epithelial cells were isolated from rat lungs according to a procedure approved by our institutional animal care committee (CIPA) of Centre de Recherche du Centre Hospitalier de l'Université de Montréal (CRCHUM) in accordance with the Canadian Council of Animal Care (CCAC) standards. Alveolar epithelial type II (ATII) cells were isolated from adult male SpragueDawley rats (6-7 weeks), according to a well-established protocol $[15,34-36]$. In brief, the lungs were washed to remove blood cells and alveolar macrophages before treatment with elastase (Worthington, Lakewood, NJ, USA). They were then minced, and the resulting suspension was filtered. Alveolar cells were collected and purified using a differential adherence technique [37], which enhances the purity of the ATII cell pool up to $86 \%[35,38]$. Although most of the macrophages are bound on IgG coated plates during this differential adherence technique, some retained in the final post-IgG cell mix (along with some red blood cells), where they likely constituted a significant proportion of non-alveolar cells in the cell prep at day 0 [38]. This freshly isolated cell suspension was seeded on Petri dishes (Corning, Fisher Scientific Ltd., Nepean, ON, Canada) or on glass slides (VWR International, Mississauga, ON, Canada) and adherent alveolar epithelial cells were cultured in minimal essential medium (MEM; Gibco, Life Technologies Inc., Burlington, ON, Canada) containing 10 \% FBS (Gibco, Life Technologies Inc.), $0.08 \mathrm{mg} / \mathrm{l}$ gentamicin, septra $(3 \mu \mathrm{g} / \mathrm{ml}$ trimethoprime $+17 \mu \mathrm{g} / \mathrm{ml}$ sulfamethoxazole), $0.2 \% \mathrm{NaHCO}_{3}$ (Sigma-Aldrich, Oakville, ON, Canada), 10 mM HEPES (Hyclone, Fisher Scientific Ltd.), and $2 \mathrm{mM} \mathrm{L}$-glutamine (Gibco, Life Technologies Inc.), as previously described $[15,35]$. The MEM-FBS-septra medium was replaced after 3 days by the same MEM-FBS without septra.

\section{Wound-healing assay}

ATII cells, cultured for 3-4 days, were injured mechanically with a pipette tip (six wounds per Petri dish) according to a highly reproducible technique $[15,16,39-42]$. This commonly employed "wound-healing assay" allows for the study of early mechanisms engaged after injury, i.e. cell migration and proliferation [39]. A mark on the Petri dishes enabled us to photograph the wounds at exactly the same place at various times (at time 0 after injury and after $24 \mathrm{~h}$ of repair). The rate of wound closure, presented in $\mu^{2} / \mathrm{h}$, was calculated with ImageJ software (National Institutes of Health, Bethesda, MD, USA) from the wound area measured after repair compared with the initial wound area, for each wound.

\section{Proliferation assay}

ATII cells were seeded at low density $\left(52,000 / \mathrm{cm}^{2}\right)$ in $35-$ $\mathrm{mm}$ Petri dishes for 3 days in MEM-FBS-septra medium and then exposed or not to TRAM-34 (Sigma-Aldrich) for a 24-h period. Cell growth was evaluated by counting the number of ATII cells by separation with trypsin-EDTA (0.05\%, Gibco, Life Technologies Inc.) before (at day 3, T0) and after (at day 4, T24h) treatment. The absence of drug cytotoxicity was verified by trypan-blue exclusion assay. The number of ATII cells was also counted at day 3 after transfection with negative control or KCa3.1 siRNAs (see section on siRNA transfection).

\section{Cell migration assays}

ATII cell migration was first evaluated by Boyden-type chamber assays, as previously described [15, 39]. Briefly, primary ATII cells were separated with trypsin-EDTA (Gibco, Life Technologies Inc.), counted, and their viability was verified with Trypan blue assay (Sigma-Aldrich). A series of experiments was also performed on ATII cells previously transfected with negative control or $\mathrm{KCa} 3.1$ 
siRNAs (see section on siRNA transfection). The cell suspensions (75,000 cells in FBS-free MEM) were placed in the upper compartment of $8-\mu \mathrm{m}$ pore filters $\left(0.33 \mathrm{~cm}^{2}\right.$, ThinCerts-TC inserts, Greiner Bio-one; MJS Biolynx, Brockville, ON, Canada) coated on the lower side with a gelatin (control condition, Sigma-Aldrich) or fibronectin matrix (Sigma-Aldrich). The lower compartment was filled with FBS-free MEM in the absence or presence of TRAM34. After an 18-h migration period, the filters were washed with PBS, the cells were fixed with paraformaldehydeacetone solution and then stained with hematoxylin (Sigma-Aldrich). Non-migrating cells in the upper compartment were scraped off with cotton-tipped applicators (Fisher Scientific Ltd.), whereas migrating cells on the lower face of the filters were counted in different randomly chosen fields under a light-inverted microscope at x20 magnification. Two-D cell migration rates $(\mu \mathrm{m} / \mathrm{h})$ of single cells were also evaluated by single-cell tracking in live-video microscopy experiments. Images were captured at 5-min intervals over a 24-h period by digital camera connected to Zeiss microscope. The migration rates and cell trajectories were analyzed by AxioVision software (Carl Zeiss, Jena, Germany).

\section{Immunoblotting of enriched ATII membrane fractions and} co-immunoprecipitation of KCa3.1 and B1-integrin

For enriched membrane fraction assays, ATII cells were scraped into TRIS-sucrose buffer $(20 \mathrm{mM}$ TRIS $\mathrm{HCl}$ (Life Technologies Inc.), 5 mM EDTA (ACP, Montréal, QC, Canada), $200 \mathrm{mM}$ sucrose (Sigma-Aldrich), protease inhibitor cocktail (Complete Mini EDTA-free protease inhibitor cocktail, Roche Applied Science, Laval, QC, Canada)) and then homogenized with a glass putter for $1 \mathrm{~min}$. Cell lysates were centrifuged $15 \mathrm{~min}$ at 3,000 rpm $\left(4{ }^{\circ} \mathrm{C}\right)$, supernatants were collected and then centrifuged at $38,000 \mathrm{rpm}$ for $1 \mathrm{~h} 30$ at $4{ }^{\circ} \mathrm{C}$. Supernatants were harvested and enriched membrane fractions in pellet were resuspended in lysis buffer $(150 \mathrm{mM} \mathrm{NaCl}$ (ACP), $50 \mathrm{mM}$ Tris- $\mathrm{HCl}, \mathrm{pH}$ 7.6, 1 \% Triton X-100 (Fisher Scientific Ltd.), 0.1 \% SDS (Bioshop Canada Inc., Burlington, ON, Canada), protease inhibitor cocktail). Protein concentrations were then measured by Bradford assay and immunoblotting was conducted as described below.

For co-immunoprecipitation assays, ATII cell lysis was performed in buffer $1(150 \mathrm{mM} \mathrm{NaCl}, 50 \mathrm{mM}$ Tris- $\mathrm{HCl}$, pH 7.5, 1 \% Nonidet P40, and $0.5 \%$ sodium deoxycholate) from the immunoprecipitation kit (protein $\mathrm{A}$, Roche Applied Science) following the manufacturer's instructions. The lysates were homogenized and isolated by centrifugation. After quantification using the Bradford method, 1-2 mg proteins from the soluble lysate were precleared with $50 \mu \mathrm{l}$ of $50 \%$ protein A-agarose suspension. The precleared soluble lysates were then incubated for 1-2 h with a rabbit anti-KCa3.1 antibody
(APC-064, Alomone Labs, Jerusalem, Israel) [43] or a mouse anti- $\beta 1$-integrin antibody (610467, BD Biosciences, Mississauga, ON, Canada). The immunocomplexes were precipitated by overnight incubation at $4{ }^{\circ} \mathrm{C}$ with $50 \mu \mathrm{l}$ of $50 \%$ protein A-agarose suspension. After being washed twice with both buffer 1 (see composition above) and buffer $2(500 \mathrm{mM} \mathrm{NaCl}, 50 \mathrm{mM}$ Tris- $\mathrm{HCl}$, $\mathrm{pH} 7.5,0.1 \%$ Nonidet P40, $0.05 \%$ sodium deoxycholate) and then once with buffer $3(10 \mathrm{mM}$ Tris $\cdot \mathrm{HCl}, \mathrm{pH} 7.5$, $0.1 \%$ Nonidet P40, $0.05 \%$ sodium deoxycholate), proteins bound to beads were collected by centrifugation and eluted by $30-50 \mu \mathrm{l}$ of $2 \mathrm{X}$ sample buffer $(62.5 \mathrm{mM}$ Tris-HCl, pH 6.8, 2 \% SDS, 10 \% glycerol, 0.2 \% bromophenol blue, $4 \% \beta$-mercaptoethanol). Control assays, in the absence of lysate or antibodies during IP, have also been performed.

Enriched membrane fraction proteins and immunoprecipitated proteins were then separated by SDS-PAGE and transferred onto nitrocellulose membranes (GE Healthcare, Mississauga, ON, Canada) according to a well-established laboratory protocol $[15,36]$. After blocking, the membranes were incubated with anti-KCa3.1 (APC-064, Alomone Labs), anti- $\beta 1$-integrin (610467, BD Biosciences) or antiTRPC4 (ACC-018, Alomone Labs) antibodies. After washing, the membranes were incubated with goat anti-rabbit (for KCa3.1 and TRPC4, Cell Signaling Technology, Danvers, MA, USA) and goat anti-mouse (for $\beta 1$ integrin, Millipore, Etobicoke, ON, Canada) IgG linked to horseradish peroxidase for $1 \mathrm{~h}$. The intensity of each specific band was quantified with ChemiDoc XRS+ Molecular Imager and Image Lab software (Bio-Rad, Mississauga, ON, Canada).

\section{Immunofluorescence assay}

ATII cells were seeded at low confluency on glass coverslips. On day 3, cells were fixed in $4 \%$ paraformaldehyde (Electron Microscopy Sciences, Hatfield, PA, USA) in PBS for $20 \mathrm{~min}$ and permeabilized with $0.1 \%$ triton X100 in PBS for $10 \mathrm{~min}$ at room temperature. After blocking in PBS containing $5 \%$ bovine serum albumin (Fisher Scientific Ltd.) for 1 h30, cells were incubated with specific anti-KCa3.1 and $\beta 1$-integrin antibodies for $1 \mathrm{~h} 30$. Absence of background signal and non-specific staining was verified in control experiments, by omitting primary antibodies. Cells were then incubated with antirabbit-CF633 (Sigma-Aldrich, for KCa3.1 detection) or Alexa Fluor 488-conjugated anti-mouse (Life Technologies Inc., for $\beta 1$-integrin detection) antibodies for $45 \mathrm{~min}$. Slides were finally rinsed and counterstained with DAPI (Sigma-Aldrich). Fluorescent images were captured with an ExiAqua camera (QImaging, Surrey, $\mathrm{BC}$, Canada) connected to an Olympus fluorescence microscope (Olympus, Richmond Hill, ON, Canada). 


\section{Small interfering (si)RNA transfections}

After isolation, ATII cells in suspension were transfected with a combination of Lipofectamine ${ }^{\mathrm{Tx}}$ RNAiMAX (Invitrogen) and Universal negative control or KCa3.1 siRNAs (Sigma-Aldrich). Five $h$ after seeding, fresh complete MEM was added onto cells, which were then primary cultured for 3 to 4 days. Efficient transfection (>80 \%) was observed in these conditions and KCa3.1 silencing $(>70 \%)$ was verified by PCR (see below).

\section{PCR amplifications}

Five $\mu \mathrm{g}$ of total RNA purified from ATII cells with TRIzol reagent (Life Technologies Inc.) was reversetranscribed into cDNA with MMLV reverse transcriptase (RT, Life Technologies Inc.) in the presence of oligodT primers (Invitrogen, Life Technologies Inc.). cDNAs were amplified with Taq polymerase (Life Technologies Inc.) and specific primers designed from sequences of rat KCa3.1 and TRPC channels: KCa3.1 5' -gctgttcatgact gacaacg- $3^{\prime}$ and $5^{\prime}$-catagccaatggtcaggaac- $3^{\prime}$, 500-bp pro duct; TRPC1 5' - gattttgggaaatttctaggaatg- $3^{\prime}$ and $5^{\prime}$-ctcat gatttgctatcagctgg-3', 363-bp product; TRPC2 5' - cgttcca gtttctcttctggaccat- $3^{\prime}$ and $5^{\prime}$ - agcatcgtcctcgatcttctgg-3', 1 91-bp product; TRPC3 $5^{\prime}$ - tgatgaggtgaacgaaggtgaactg- $3^{\prime}$ and $5^{\prime}$ - tgcccacatttgtgccagagtca-3', 206-bp product; TR PC4 $5^{\prime}$ - tctgcagatatctctgggaaggatgc- $3^{\prime}$ and $5^{\prime}$ - aagctttgtt cgagcaaatttccattc-3', 415-bp product; TRPC5 5'- cccgg catgaattcacggag- $3^{\prime}$ and $5^{\prime}$ - catggtcggcaatgagctggtag- $3^{\prime}$, 129-bp product; TRPC6 $5^{\prime}$ - gagaacataggctatgttctgtatggag tc- $3^{\prime}$ and $5^{\prime}$ - gccatcatcctcaatttcctgg- $3^{\prime}, 114-$ bp product; TRPC7 $5{ }^{\prime}$ - tccctttaacctggtgccgagtc- $3^{\prime}$ and $5^{\prime}-$ ttcagcatg cccatttccagg-3', 129-bp product. Primer pairs were designed in distinct exons to avoid genomic DNA amplification. RT-PCR amplification was undertaken according to a well-established laboratory protocol $[35,36,44]$. PCR products were normalized with the $\beta$-actin signal for each cDNA sample ( $\beta$-actin $5^{\prime}$-ctaaggccaaccgtgaaaag-3' and $5^{\prime}$ - gccatctcttgctcgaagtc-3', 311-bp product). The RT-PCR products were finally separated on agarose gels, stained with SYBR Safe (Life Technologies Inc.). Signals were detected by Typhoon Gel Imager and analyzed by ImageQuant software (Molecular Dynamics, Baie d'Urfé, QC, Canada) [35, 36, 44].

\section{Fura-2 calcium imaging}

Intracellular calcium concentration $\left(\left[\mathrm{Ca}^{2+}\right]_{\mathrm{i}}\right)$ was monitored using the fluorescent dye Fura-2. Briefly, ATII cells cultured on coverslips were loaded $\left(1 \mathrm{~h} 15\right.$ at $\left.37^{\circ} \mathrm{C}\right)$ with $5 \mu \mathrm{M}$ Fura-2-AM (Life Technologies Inc.) in MEM containing $0.04 \%$ pluronic F127 (Life technologies Inc.) followed by a 45 min de-esterification in MEM. Coverslips with loaded cells were then mounted in the imaging chamber on the stage of an inverted microscope (Nikon TE300, Mississauga, ON, Canada) and bathed with a physiological saline solution (PSS, $140 \mathrm{mM}$ $\mathrm{NaCl}, 5 \mathrm{mM} \mathrm{KCl}, 1 \mathrm{mM} \mathrm{MgCl}, 2 \mathrm{mM} \mathrm{CaCl}, 11.1 \mathrm{mM}$ glucose, 10 mM HEPES, $\mathrm{pH}$ 7.4). To measure the $\mathrm{Ca}^{2+}$ permeability through ATII cell plasma membranes, PSS was replaced by the same solution without $\mathrm{Ca}^{2+}$ and supplemented with $1 \mathrm{mM}$ EGTA (PSS $0 \mathrm{Ca}^{2+}$ ). Cells were then alternately excited at 340 and $380 \mathrm{~nm}$ with a high-pressure mercury lamp via interference filters (Chroma Technology, Brattleboro, VT, USA) mounted on a filter wheel (Sutter Lamba 10-C, Sutter Instrument, Novato, CA, USA) with a dichroic mirror $(510 / 540 \mathrm{~nm}$, Chroma Technology). Fluorescence images were recorded at 5-s intervals by digital camera using Metafluor software (Molecular Devices, Guelph, ON, Canada) and analyzed with Metafluor Analysis (Molecular Devices). Fura-2 fluorescence measurements (corresponding to the mean fluorescence values of 30 cells/field) are presented as $\left[\mathrm{Ca}^{2+}\right]_{\mathrm{i}}$, which was calculated accordingly to the Grynkiewicz equation [45], using a $\mathrm{Kd}$ of $225 \mathrm{nM}$. Rmax was determined by the addition of digitonin $(4 \mu \mathrm{M}$, SigmaAldrich) to PSS $\left(2 \mathrm{mM} \mathrm{Ca}{ }^{2+}\right)$ and Rmin by subsequent addition of ethylene glycol-bis ( $[\beta$-amino-ethyl ether)$\mathrm{N}, \mathrm{N}, \mathrm{N}, \mathrm{N}$ '-tetraacetic acid (EGTA) at a final concentration of $20 \mathrm{mM}$.

\section{Statistical analysis}

The data are presented as mean \pm standard error of the mean (SEM). Statistical analyses were performed with GraphPad Prism version 5 for Windows (GraphPad software, San Diego, CA, USA) using Wilcoxon signed rank test and one sample sign test. Two-way Anova tests were performed with IBM SPSS Statistics 22 (IBM Corp., Armonk, NY). Differences were considered significant when $p<0.05$.

\section{Results}

\section{Involvement of KCa3.1 in ATII epithelial repair on} fibronectin matrix

A well-established wound-healing assay with mechanical injury of primary ATII cell monolayers was used to study the contribution of KCa3.1 channels in the healing process. We first observed that the presence of TRAM$34(5$ and $10 \mu \mathrm{M})$, a specific $\mathrm{KCa} 3.1$ inhibitor, did not affect the wound-healing rates of ATII cell monolayers in the absence of coating (Fig. 1b). In agreement with data from the literature [12], we then confirmed that the wound-closure rates of ATII cell monolayers grown on a fibronectin matrix were higher $\left(38.3 \pm 3.0 \times 10^{3} \mu^{2} / \mathrm{h}\right)$ compared to cells cultured in the absence of matrix $\left(30.5 \pm 3.1 \times 10^{3} \mu \mathrm{m}^{2} / \mathrm{h}\right)$, i.e. an increase of $7.8 \times 10^{3} \mu^{2} / \mathrm{h}$ $(p<0.04$, Fig. 1a and b). This stimulatory effect was partially prevented by an anti- $\beta 1$-integrin antibody (decrease of $3.5 \times 10^{3} \mu \mathrm{m}^{2} / \mathrm{h}, p<0.02$, not shown). 
A

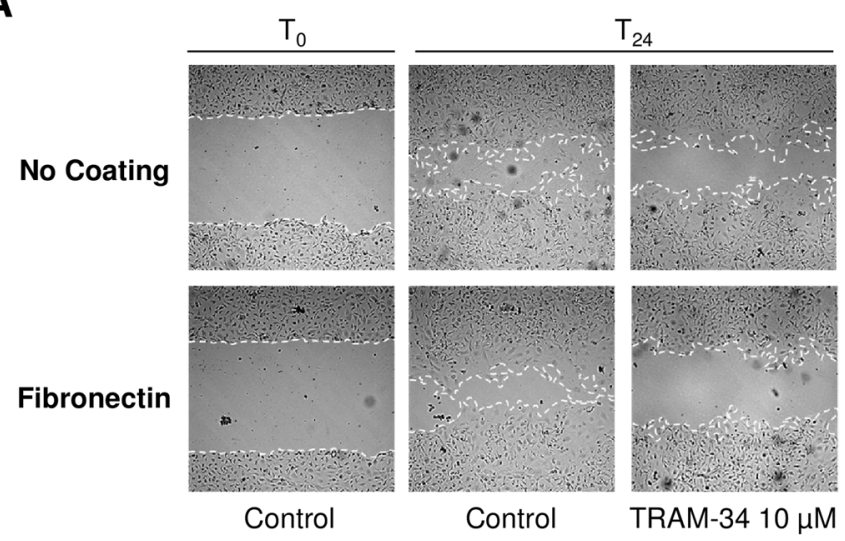

B

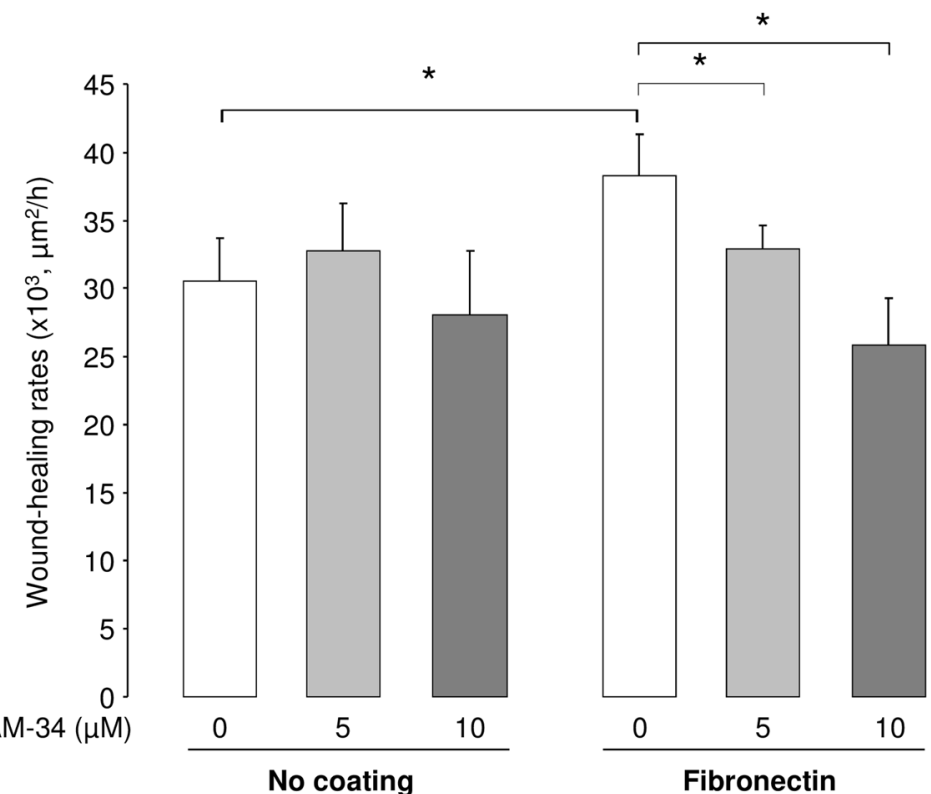

Fig. 1 Impact of KCa3.1 inhibition on fibronectin-stimulated ATIl wound repair. ATIl cell monolayers, grown in the absence (no coating) or presence of fibronectin coating, were injured mechanically and wound-healing rates were measured over a 24-h period, in the presence or absence of the KCa3.1 inhibitor TRAM-34. Representative photographs ( $x 4$ magnification) at time $0\left(T_{0}\right)$ and $24 \mathrm{~h}\left(\mathrm{~T}_{24}\right)$ after injury in each condition are presented in (a). The wound edge is indicated by the dotted lines. $\mathbf{b}$. Mean wound-closure rates $\left(\mu \mathrm{m}^{2} / \mathrm{h}\right)$ are compared in control $(0)$ and TRAM-34 $(5$ and $10 \mu M)$ treated monolayers, in the absence or presence of fibronectin coating $(n=6) .{ }^{*} p<0.05$

We also observed a dose-dependent reduction of fibronectin-stimulated wound-healing rates after $\mathrm{KCa} 3.1$ inhibition (15 and $33 \%$ inhibition in the presence of 5 and $10 \mu \mathrm{M}$ TRAM-34 respectively, Fig. 1b). In a previous study [15], we demonstrated an involvement of two other types of $\mathrm{K}^{+}$channels, i.e. KvLQT1 and $\mathrm{K}_{\mathrm{ATB}}$ during alveolar repair which did not required fibronectin coating. We now verified that the wound healing rate on fibronectin coating $\left(47.0 \pm 3.8 \times 10^{3} \mu \mathrm{m}^{2} / \mathrm{h}\right)$ was also significantly reduced in the presence of KvLQT1 and $K_{\text {ATP }}$ inhibitors (i.e., clofilium $(5 \mu \mathrm{M})$ and glibenclamide (10 $\mu \mathrm{M}), 32.1 \pm 5.0 \times 10^{3} \mu^{2} / \mathrm{h}, p<0.04$, not shown). Moreover, the combination of TRAM-34 (20 $\mu \mathrm{M})$, with clofilium and glibenclamide, elicited an additional inhibitory effect of the repair rates on fibronectin $(24.4 \pm 4.4 \times$ $10^{3} \mu \mathrm{m}^{2} / \mathrm{h}, p<0.04$, not shown).

Our data point to an involvement of $\mathrm{KCa} 3.1$ channels in the regulation of ATII wound repair in the presence of a fibronectin matrix. We then undertook complementary experiments to further assess the role of $\mathrm{KCa} 3.1$ in two crucial processes of epithelial repair, i.e. cell proliferation and migration.

\section{Impact of KCa3.1 inhibition on ATII cell growth}

ATII cell growth was evaluated by counting the number of cells at day 3 and 4 in subconfluent primary cultures, 
exposed to 5, 10 and $20 \mu \mathrm{M}$ TRAM-34 over the 24-h period (day 3 to day 4). Similar to wound-healing assays, we observed that ATII cell growth was not affected by KCa3.1 inhibition with TRAM-34 in the absence of fibronectin coating (Fig. 2a). However, TRAM-34 significantly decreased the growth of ATII cells cultured on fibronectin matrix (19, 17 and $24 \%$ reduction in presence of 5, 10 and $20 \mu \mathrm{M}$ TRAM-34 respectively, Fig. 2b).

\section{Involvement of KCa3.1 in ATII cell motility}

The role of KCa3.1 in ATII cell motility was assessed using two complementary approaches. Boyden-type chamber assays first showed that TRAM-34 exposure did not decrease the number of migrating cells in control conditions (absence of fibronectin matrix) (Fig. 3a, left panel), whereas fibronectin-stimulated cell migration was significantly reduced by TRAM-34 (12, 19 and $23 \%$ inhibition in the presence of 5,10 and $20 \mu \mathrm{M}$ TRAM-34 respectively, Fig. 3a, right panel). The involvement of KCa3.1 in 2D cell migration dynamics was then assessed by single-cell tracking in subconfluent ATII cell cultures using time-lapse video-microscopy experiments. As depicted in Fig. 3b, TRAM-34 did not impact ATII cell trajectories and migration rates in the absence of coating (left panels, no coating). On the contrary, ATII cell trajectories on fibronectin matrix were altered by TRAM34 and the mean migration rate $(37 \mu \mathrm{m} / \mathrm{h}$ in absence of TRAM-34) was decreased to 31,25 and $24 \mu \mathrm{m} / \mathrm{h}$ in the presence of 5,10 and $20 \mu \mathrm{M}$ TRAM-34, respectively (Fig. 3b, right panels). These results demonstrated a crucial role of KCa3.1 channels in the control of ATII cell motility on fibronectin.

\section{Impact of KCa3.1 silencing on wound healing, cell proliferation and migration}

To confirm the role of KCa3.1, we then adopted a complementary approach with specific KCa3.1 siRNAs. After verification of siRNA efficiency (Fig. 4a), we showed that KCa3.1 down-regulation did not reduced alveolar repair in the absence of coating (Fig. 4b, left), whereas it was associated with a significant decrease in wound-healing $\left(28.8 \pm 2.3 \times 10^{3} \mu^{2} / \mathrm{h}\right.$ in the presence of $\left.\mathrm{KCa} 3.1 \mathrm{siRNA}\right)$, compared to ATII cells exposed to negative control siRNA $\left(33.9 \pm 1.7 \times 10^{3} \mu \mathrm{m}^{2} / \mathrm{h}, P<0.05\right.$, Fig. $4 \mathrm{~b}$, right $)$ on fibronectin coating. The number of ATII cells at day 3 after transfection with negative control and KCa3.1 siRNAs was similar in non-coated conditions, whereas a small, non-significant decrease in cell proliferation was noted on fibronectin coating in the presence of $\mathrm{KCa} 3.1$ siRNA (Fig. 4c). We also observed that the number of migrating cells through a Boyden type chamber was significantly reduced after $\mathrm{KCa} 3.1$ silencing (siKCa3.1) in the presence of fibronectin, but not in the absence of matrix (Fig. 4d).

\section{Wound healing stimulation by KCa3.1 activation}

Because our data with TRAM-34 and siRNA indicated that alveolar wound repair on fibronectin matrix is, at least in part, dependent on KCa3.1 function, we next explored a potential beneficial impact of $\mathrm{KCa} 3.1$ activation on ATII wound-healing. As presented in Fig. 5, the repair rates of ATII cell monolayers grown in the absence

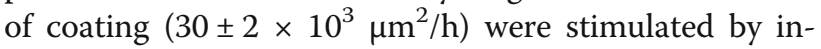
creasing concentrations of 1-EBIO. This $\mathrm{KCa}$ activator also enhanced the fibronectin-stimulated wound repair, reaching a rate of $42 \pm 3 \times 10^{3} \mu \mathrm{m}^{2} / \mathrm{h}$ in the presence of coating and $200 \mu \mathrm{M}$ 1-EBIO.

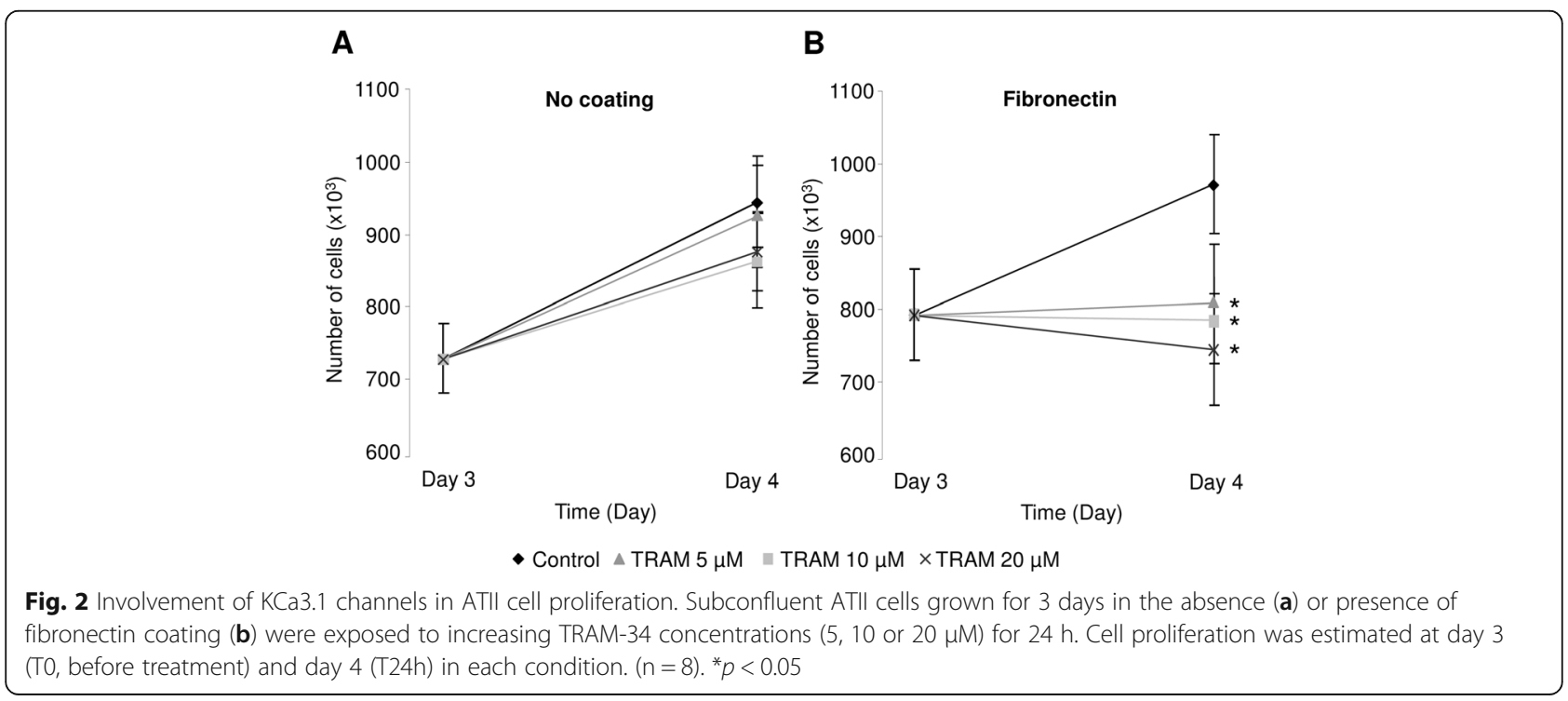



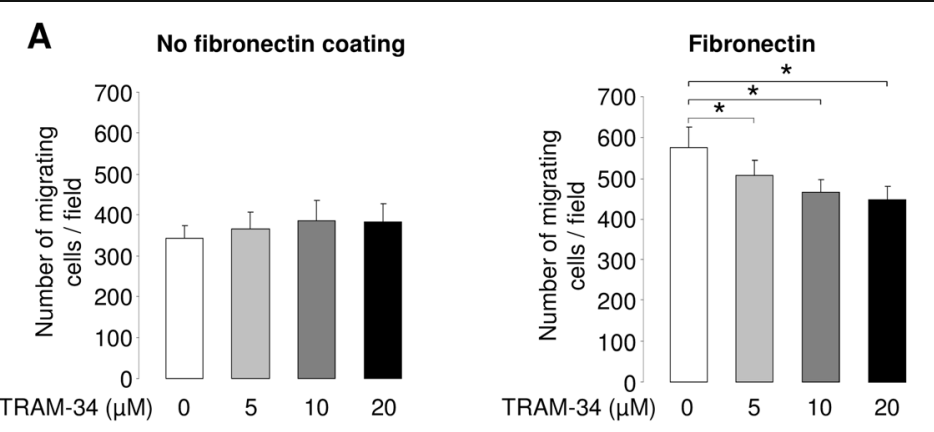

B
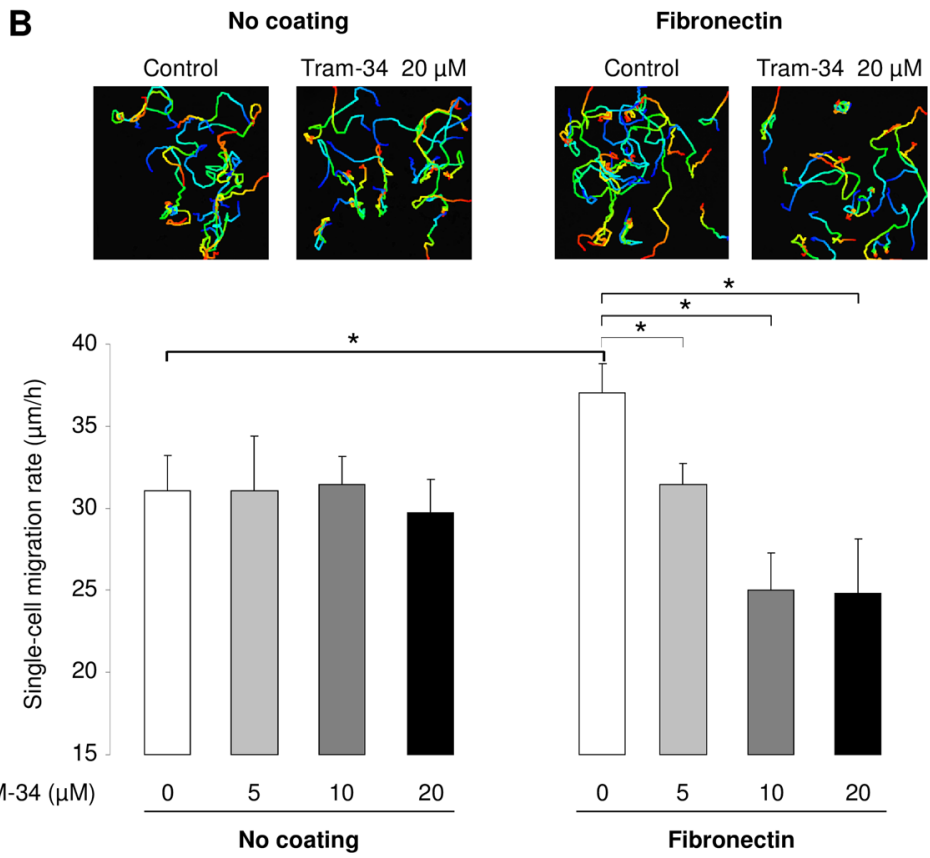

Fig. 3 Impact of KCa3.1 inhibition on ATII cell motility. ATIl cell migration was evaluated using Boyden-type assays (a) and single cell tracking in live time-lapse videomicroscopy (b). The number of migrating ATII cells were measured over an 18-h period in the absence (0) or presence of 5, 10 or $20 \mu \mathrm{M}$ TRAM-34 and compared in the absence (a, no fibronectin coating, left panel) or presence of fibronectin (a, right panel) (5 fields/ insert, 3 inserts/condition, $n=4-6)$. 2D cell migration rates (b) were evaluated by ATIl single-cell tracking ( 15 cells/field, 2 fields/condition/ experiment, $n=6)$ over a 24-h period in the absence (0) or presence of TRAM-34 $(5,10$ and $20 \mu M)$. Representative trajectories of ATIl cells in the absence or presence of a fibronectin matrix, in control condition and in the presence of $20 \mu \mathrm{M}$ TRAM-34 are presented in the top panel (b). Colors indicate 0 -h (blue) to $24-h$ (red) time points. ${ }^{*} p<0.05$

\section{Relationship between KCa3.1 channels and $\beta 1$-integrin}

Based on our data indicating a cooperative role played by $\mathrm{KCa} 3.1$ and fibronectin matrix in alveolar wound repair, we then decided to further investigate a possible relationship between the $\mathrm{KCa} 3.1$ channel and the $\beta 1$-integrin, a receptor and signal transducer of fibronectin [12].

We first explored a possible spatial co-distribution of KCa3.1 channel and $\beta-1$ integrin. As shown in Fig. 6a, both $\mathrm{KCa} 3.1$ and $\beta 1$-integrin proteins were detected by immunofluorescence assays in ATII cells. More importantly, these two proteins were predominantly codistributed at the plasma membrane (Fig. 6a, top merge panel). It should be noted that there was no, or very diffuse, signal with secondary antibodies in control experiments in the absence of respective primary antibodies (Fig. 6a, negative controls).

We then assessed a possible assembly of these two proteins using co-immunoprecipitation assays. Expression of $\beta 1$-integrin and $\mathrm{KCa} 3.1$ proteins was first confirmed by western blotting on ATII cell extracts (Fig. 6b, lane 1, « total lysate »), where doublets of 120-105 (mature and immature $\beta 1$-integrin proteins, IB: $\beta 1$-integrin) and $51 \mathrm{kDa}$ (IB: KCa3.1) bands were detected using anti- $\beta 1$-integrin and anti-KCa3.1 antibodies, respectively. Interestingly, $\mathrm{KCa} 3.1$ proteins was 

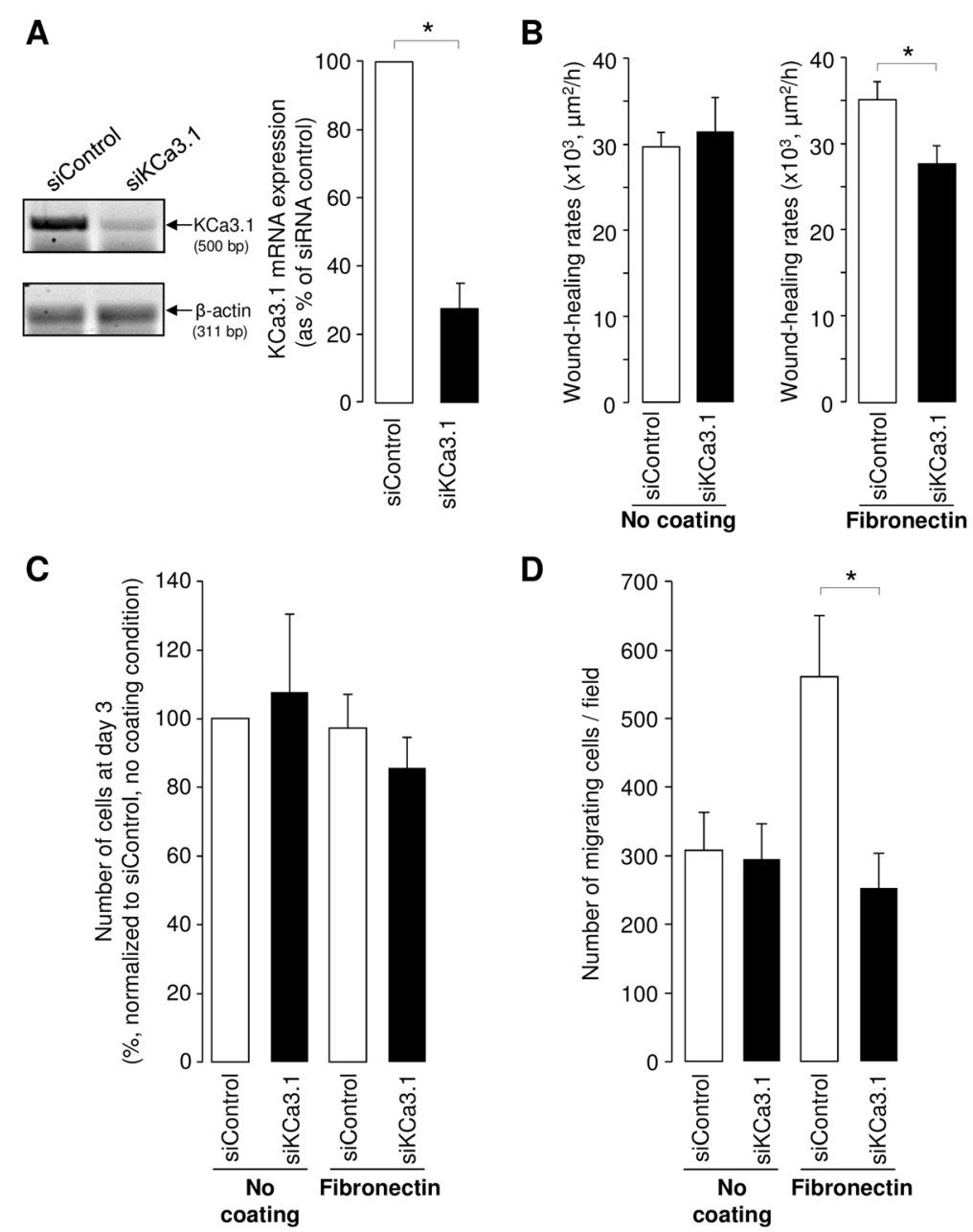

D

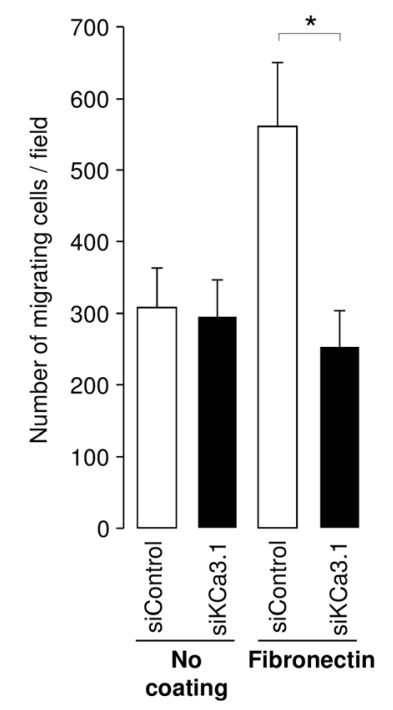

Fig. 4 Delayed ATII wound repair and reduced cell proliferation and migration after KCa3.1 silencing in the presence of fibronectin coating. ATII cells were transfected with negative control siRNA (siRNA control) or siRNAs directed against KCa3.1 (siKCa3.1) and then seeded in the absence or presence of fibronectin coating. KCa3.1 silencing was verified by PCR $(\mathbf{a}, n=7)$. A representative agarose gel is presented on the left. (b) Wound-healing rates (in $\mu \mathrm{m}^{2} / \mathrm{h}$ ) were measured at $24 \mathrm{~h}$ after injury among cells transfected with control or KCa3.1 siRNAs in the absence of coating (left) and in the presence of fibronectin matrix (right) ( $n=7$ ). The number of ATIl cells was counted at day 3 of culture after transfection with control or KCa3.1 siRNAs $(n=14, \mathbf{c})$. The number of migrating ATII cells, transfected 3 days before with control or KCa3.1 siRNAs, was measured in a Boyden type chamber over an 18-h period in the absence (no coating) or presence of fibronectin ( $n=6, \mathbf{d}$ ). ${ }^{*} p<0.05$

also detected after immunoprecipitation (IP) using anti- $\beta 1$-integrin antibody (Fig. 6b, lane 2 , « $\beta 1$-integrin IP », IB: KCa3.1). We also detected $\beta 1$-integrin proteins, after KCa3.1 immunoprecipitation (Fig. 6b, lane 3, « KCa3.1 IP », IB: $\beta$-integrin). This result thus showed for the first time that KCa3.1 could form an immunoprecipitable complex with the $\beta-1$ integrin in the ATII cells.

The expression levels of $\mathrm{KCa} 3.1$ and $\beta 1$-integrin proteins in enriched membrane fractions of ATII cells were then compared in the presence or absence of fibronectin coating. We noted that ATII cells grown in the presence of fibronectin matrix expressed a higher level of the KCa3.1 and $\beta 1$-integrin proteins in their membrane fractions ( $50 \%$ and $80 \%$ enhancement, respectively) compared to cells cultured in the absence of coating (Fig. 6c). This observation reinforced the hypothesis of a relationship between $\beta 1$-integrin and $\mathrm{KCa} 3.1$.

\section{Involvement of calcium transport in fibronectin- stimulated ATII wound repair}

The involvement of KCa3.1, which is a calcium-activated potassium channel [46], during ATII wound repair on fibronectin, suggested that changes in intracellular calcium may occur in these conditions. We first evaluated the variation in $\left[\mathrm{Ca}^{2+}\right]_{\mathrm{i}}$ using Fura- 2 assays in the presence and absence of fibronectin coating. We first noted that the steady-state $\left[\mathrm{Ca}^{2+}\right]_{\mathrm{i}}$ was higher $(78.8 \pm 8.8 \mathrm{nM})$ 


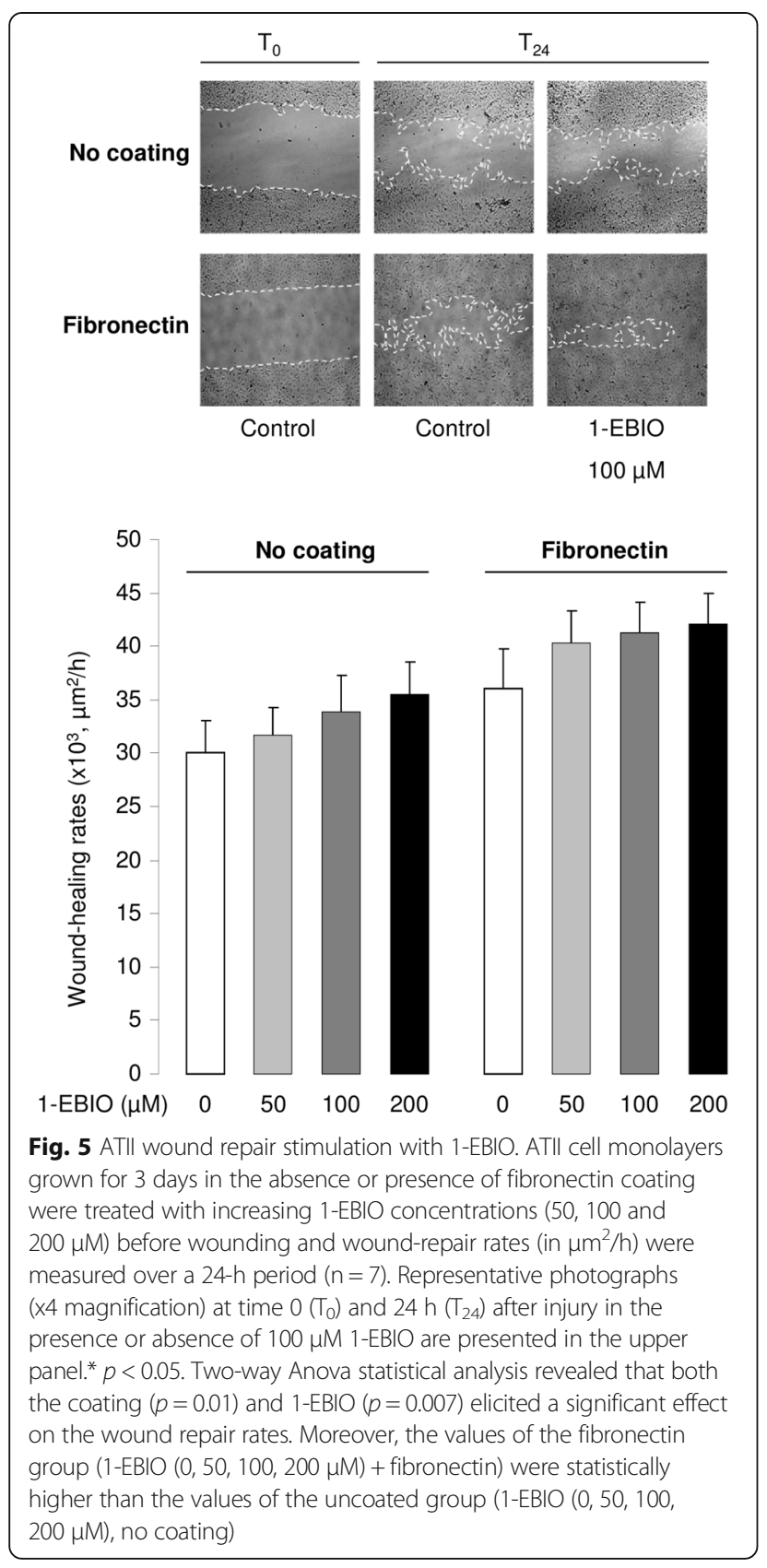

in ATII cells cultured on fibronectin compared to the control condition (absence of coating, $53.8 \pm 4.3 \mathrm{nM}$, Fig. 7a). The plasma membrane $\mathrm{Ca}^{2+}$ permeability of ATII cells was also estimated by replacing the saline solution bathing the cells, which contained $2 \mathrm{mM} \mathrm{Ca}^{2+}$, by a $\mathrm{Ca}^{2+}$ free saline solution supplemented with $1 \mathrm{mM}$ EGTA. This extracellular $\mathrm{Ca}^{2+}$ removal was followed by a reduction in $\left[\mathrm{Ca}^{2+}\right]_{\mathrm{i}}$ level of $30.3 \pm 3.1 \mathrm{nM}$ in absence of coating. Notably, the change in $\left[\mathrm{Ca}^{2+}\right]_{\mathrm{i}}$ was higher $(43.8 \pm 5.1 \mathrm{nM})$ in the presence of fibronectin (Fig. $7 \mathrm{~b})$.

Because calcium membrane transport mechanisms in ATII cells are not well defined, we decided to investigate the identity of $\mathrm{Ca}^{2+}$ channels that could be involved in the observed modifications in $\mathrm{Ca}^{2+}$ levels in cell grown on fibronectin. We focused on a subgroup of the large TRP channel family, the TRPC channels [47, 48], because at least one member of this subfamily has already been proposed as a functional partner of KCa3.1 [49]. Using RT-PCR, we detected the mRNA expression of all seven members of the TRPC family (TRPC1 to TRPC7, Fig. 8a). As shown in Fig. 8b, a huge enhancement in TRPC4 mRNA expression was observed in ATII cells cultured on fibronectin matrix (compared to the control, non-coated condition), whereas the increase in TRPC2, 3 and 5 mRNA was non-significant. Similar to KCa3.1 and $\beta 1$-integrin proteins, we also measured an enhancement of the relative level of the TRPC4 protein expressed in the enriched membrane fraction in ATII cells cultured on fibronectin (compared to no coating, Fig. 8c).

A final series of experiments was undertaken to examine the involvement of TRPC4 channels, using the specific inhibitor ML-204 [50], in fibronectin-stimulated alveolar wound repair. As previously observed after KCa3.1 inhibition with TRAM-34 (Fig. 1b), blocking of TRPC4 channels with ML-204 (Fig. 8d, ML-204) did not significantly reduce the wound-healing rates of ATII monolayers in the absence of coating, whereas ML-204 significantly decreased the rates on fibronectin matrix (fibronectin + ML-204). Finally, an additive inhibitory effect of TRAM-34 on wound-healing rates was observed, suggesting a complementary role played by $\mathrm{KCa} 3.1$ and TRPC4 channels during ATII epithelial repair on fibronectin (Fig. 8d, fibronectine + ML-204 + TRAM-34).

\section{Discussion}

Our study revealed that $\mathrm{Ca}^{2+}$-activated $\mathrm{KCa} 3.1$ channels and interactions with integrin receptor and extracellular matrix component (fibronectin) play a significant role in alveolar wound repair processes. Specifically, we highlighted a relationship between $\beta 1$-integrin, a fibronectin receptor and signal transducer, and KCa3.1 channels. We also found that the presence of a fibronectin coating is associated with elevated steady state $\left[\mathrm{Ca}^{2+}\right]_{\mathrm{i}}$ as well as $\beta 1$-integrin, $\mathrm{KCa} 3.1$ and TRPC4 channel membrane expression. Finally, our data indicate complementary roles of ECM, $\beta 1$-integrin, KCa3.1 and TRPC4 channels during alveolar repair processes (recapitulative scheme presented in Fig. 9).

The observed increases in ATII wound-healing (Fig. 1) and cell migration (Fig. 3) rates on fibronectin confirm importance of this extracellular matrix component in alveolar repair, in agreement with previous studies. Indeed, Kim et al. demonstrated using Boyden chamber assays that alveolar epithelial cell migration was increased in the presence of either soluble or coated fibronectin [12]. A role for this extracellular matrix component has also 

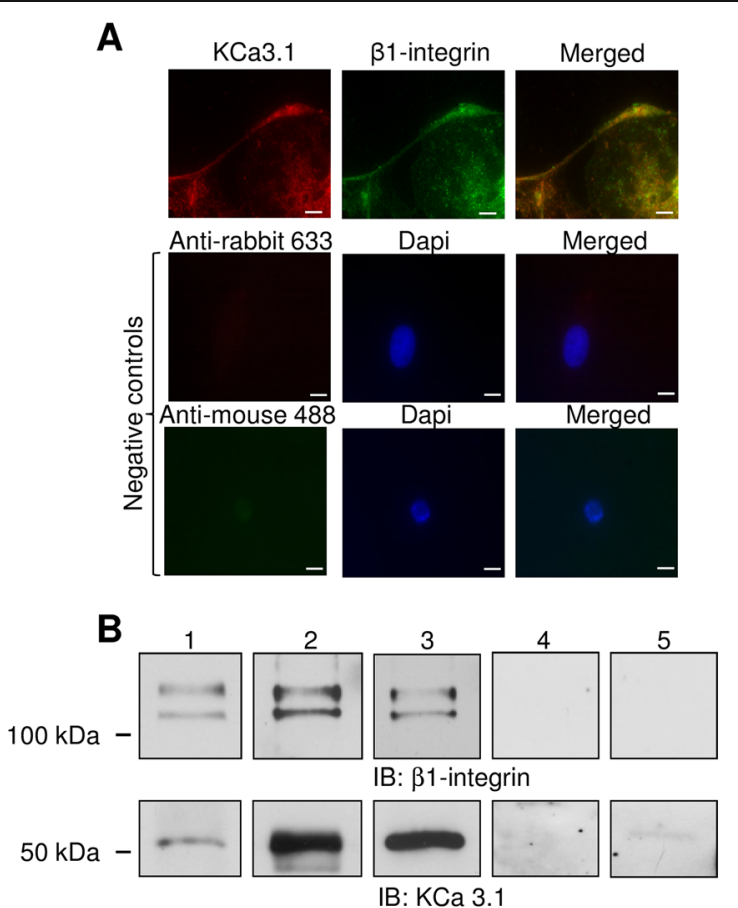

1. Total lysate

2. $\beta 1$-integrin IP

3. KCa3.1 IP

4. Negative IP control (no lysate)

5. Negative IP control (no antibody)
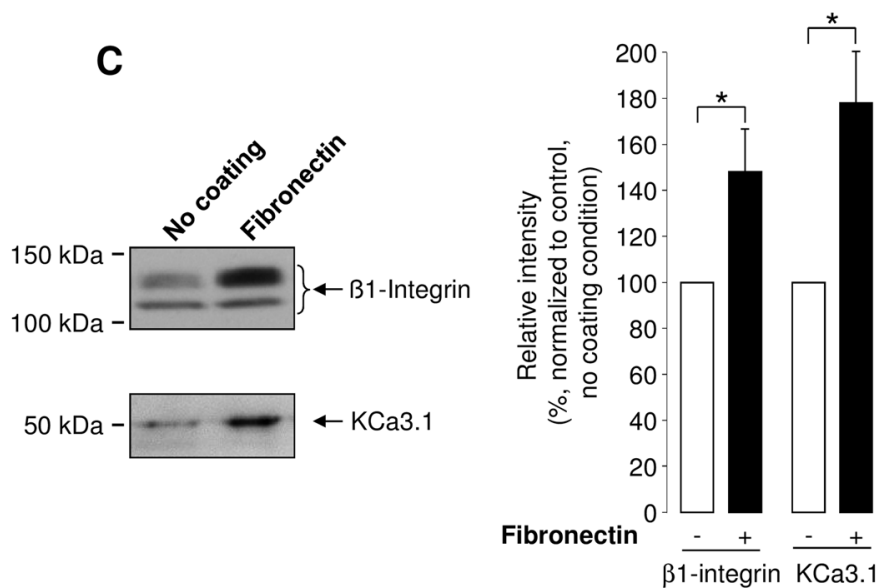

Fig. 6 Cellular co-distribution, co-immunoprecipitation and membrane expression of $\beta 1$-integrin and KCa3.1 channels. a. Representative immunofluorescence images of KCa3.1 and $\beta 1$-integrin staining performed on ATIl cells using anti-KCa3.1, anti- $\beta 1$-integrin, anti-rabbit 633 (for KCa3.1 detection) and anti-mouse 488 (for $\beta 1$-integrin detection) antibodies. Color superposition shows similar cellular distribution of KCa3.1 and $\beta 1$-integrin in ATIl cells (merge panel, Scale bars, $10 \mu \mathrm{m}$ ). No or diffuse signal was detected with the Alexa fluor 488 and Alexa fluor 633 coupled secondary antibodies in control experiments (negative controls). b. Representative immunoblots showing $\beta 1$-integrin and KCa3.1 co-immunoprecipitations. $\beta 1$-integrin (upper panels, IB: $\beta 1$-integrin) and KCa3.1 (lower panels, IB: KCa3.1) proteins were revealed with specific antibodies after $\beta 1$-integrin and KCa3.1 immunoprecipitation with anti- $\beta 1$-integrin (lane 2 « $\beta 1$-integrin IP ») or anti-KCa3.1 (lane 3 « KCa3.1 IP ») antibodies in ATII cell extracts. Endogenous expression of $\beta 1$-integrin and KCa3.1 proteins in ATIl cell lysate is also shown in lane 1, « Total Lysate ». Lanes 4 and 5 are negative control assays showing an absence of band in IB (IB $\beta$ 1-integrin and IB KCa3.1) after IP in the absence of lysate (lane 4, « Negative IP Control (no lysate) ») and in the absence of $\beta$-integrin and KCa3.1 antibodies (lane 5, « Negative IP control (no antibody) »). c. The level of $\beta 1$-integrin and KCa3.1 channel expression in membrane fractions were determined by immunoblotting using anti- $\beta 1$-integrin and anti-KCa3.1 antibodies. A representative immunoblot is shown in the left panel. The band intensities were compared in control condition (no coating, - ) and in the presence of a fibronectin $(+)$ matrix (right panel, $n=11$ ). ${ }^{*} p<0.05$

been shown in other epithelial tissues, including in the cornea [51].

One of our previous studies [15] demonstrated that KvLQT1 and $\mathrm{K}_{\mathrm{ATP}}$ channels actively participate in the control of ATII wound healing in the absence of fibronectin coating, whereas our present data (Figs. 1 and $4 \mathrm{~b}$ ) indicate that $\mathrm{KCa} 3.1$ did not affect the wound repair rates in these conditions. Interestingly, both KCa3.1 pharmacological inhibition and molecular silencing impaired fibronectin-stimulated ATII wound-repair 


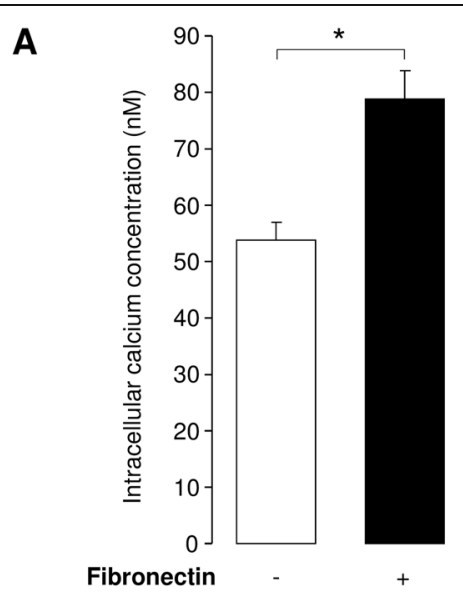

B

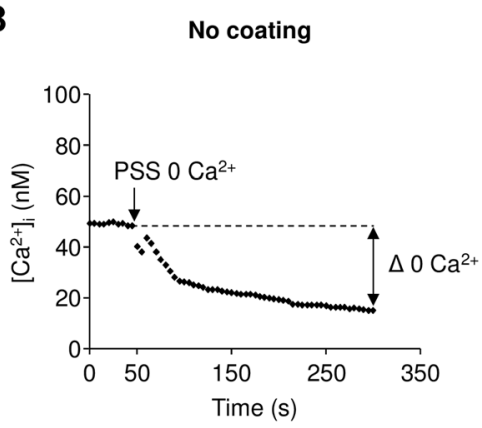

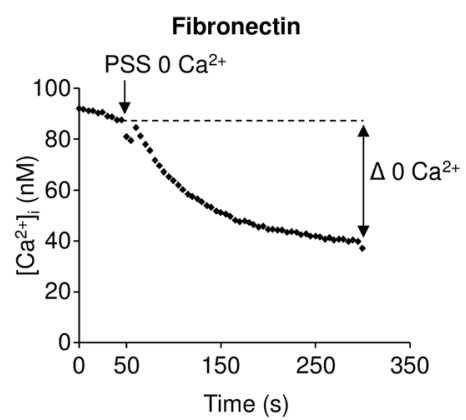

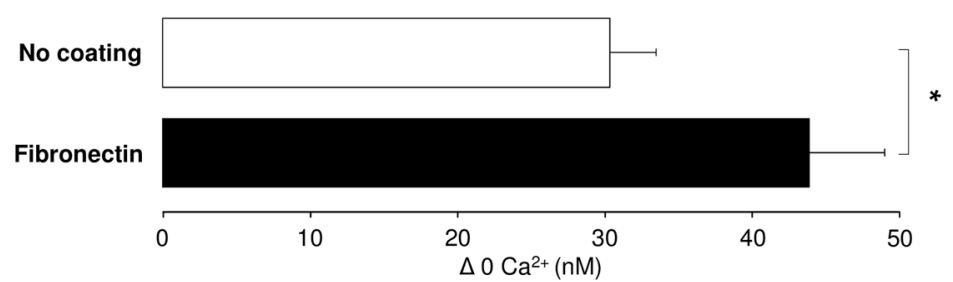

Fig. 7 Impact of fibronectin coating on calcium signal in ATII cells. a. [Ca $\left.{ }^{2+}\right]_{i}$ was measured using Fura-2 in ATIl cells bathed with a physiological saline solution containing $2 \mathrm{mM} \mathrm{Ca}^{2+}$ and compared in the absence (-) or presence (+) of fibronectin coating. b. Ca ${ }^{2+}$ permeability through ATII cell membranes was evaluated after external calcium removal. Illustrative traces showing the decrease of [Ca $\left.{ }^{2+}\right]_{i}$ as a function of time in absence (no coating) or in presence of fibronectin matrix (fibronectin) after PSS $0 \mathrm{Ca}^{2+}$ application are presented on top panels (b). The mean amplitudes of $\left[\mathrm{Ca}^{2+}\right]_{i}$ decrease were compared in the absence or in presence of fibronectin matrix (bottom panel, $\mathbf{b}$ ). $(n=10){ }^{*} p<0.05$

rates (Figs. 1 and 4b). This discrepancy could be explained by variable basal activity of KvLQT1, $\mathrm{K}_{\mathrm{ATP}}$ and KCa3.1 channels in ATII cells. Indeed, it is possible that KCa3.1 channels require a signal, through $\beta 1$-integrin activation in presence of fibronectin, to participate in ATII wound-healing processes, whereas KvLQT1 and $K_{\text {ATP }}$ channels may exhibit sufficient basal activity to regulate alveolar epithelial repair even in absence of coating. In agreement with this hypothesis our data indicated an additive effect after concomitant inhibition of KvLQT1, $\mathrm{K}_{\mathrm{ATP}}$ and KCa3.1 channels on fibronectin matrix. It could also be postulated that the TRAM-34sensitivity on fibronectin coating could be due to the observed increased expression (Fig. 6c) of KCa3.1/integrin proteins, which cooperate to regulate alveolar repair, migration and proliferation in this condition. A role for KCa3.1 channels in the control of both ATII cell proliferation and migration on fibronectin (Fig. 4) was also confirmed by the siRNA approach. Such an involvement of KCa3.1 in cell motility [52-55] or proliferation [56, 57] had previously been established in other cell types.

The observation that $\mathrm{KCa} 3.1$ function in alveolar repair is dependent on the presence of fibronectin suggests a potential link between KCa3.1 and extracellular matrix receptors, such as integrins. In agreement with this hypothesis, our immunofluorescence and co-immunoprecipation experiments (Fig. 6) demonstrate for the first time a cellular codistribution and a potential physical link between $\mathrm{KCa} 3.1$ and $\beta 1$-integrin in ATII cells. Although such observations have never been reported before in native epithelial cells, 

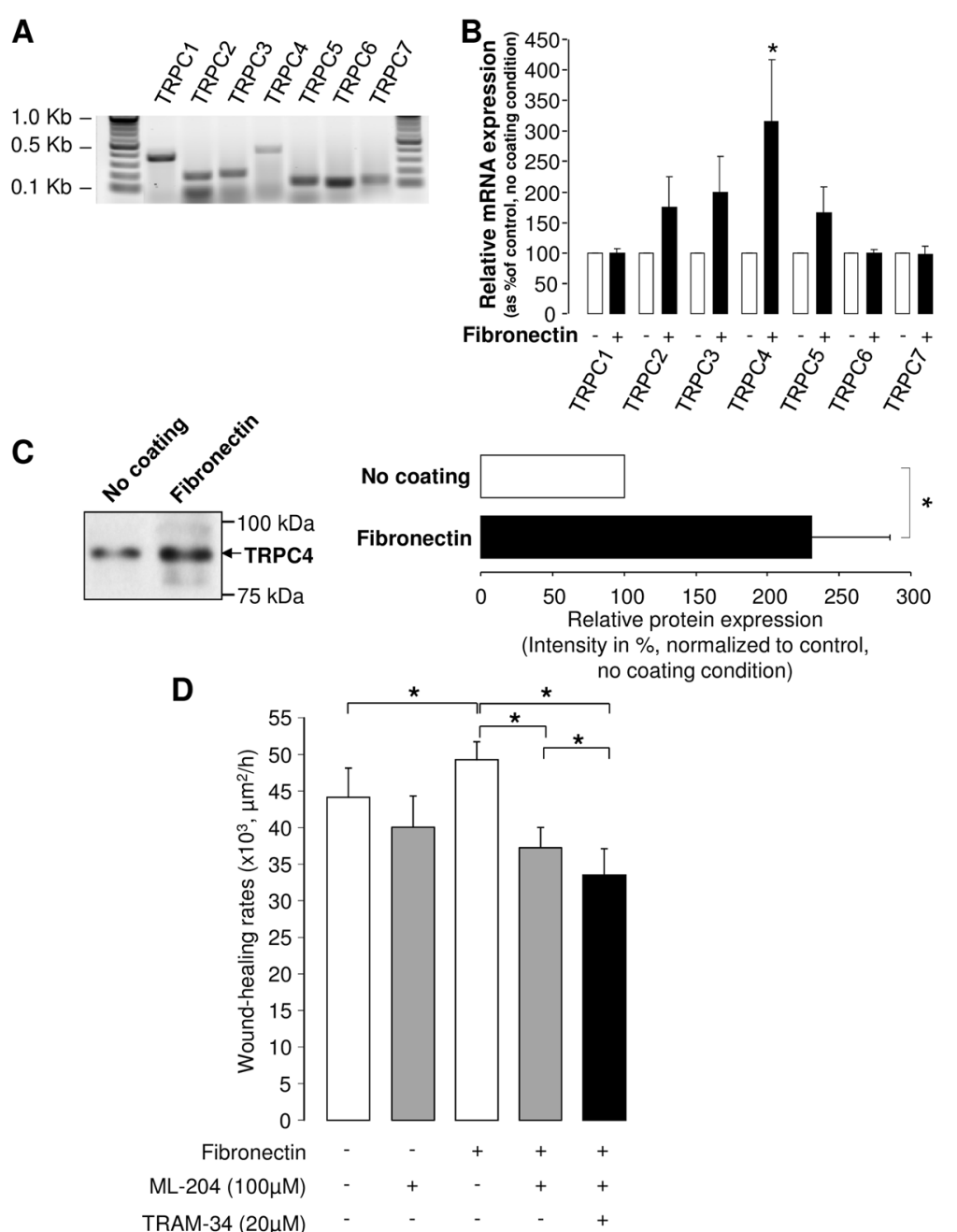

Fig. 8 Expression of TRPC channels in ATIl cells and complementary roles of TRPC4 and KCa3.1 in wound repair on fibronectin matrix. Representative agarose gel showing PCR products amplified from ATII CDNA with PCR primer pairs designed from rat TRPC channels (a). TRPC channel relative mRNA expressions were normalized to $\beta$-actin and compared between no coating and fibronectin matrix conditions $(\mathbf{b}, \mathrm{n}=16-20)$. $\mathbf{c}$. Levels of TRPC4 protein expression in membrane fractions were measured by immunoblotting using specific anti-TRPC 4 channel antibody and band intensities were compared between control (no coating) and fibronectin matrix conditions (c, right panel, $\mathrm{n}=11$ ). A representative immunoblot is shown in the left panel. $\mathbf{d}$. ATII cells, cultured in the absence $(-)$ or presence $(+)$ of a fibronectin coating, were injured mechanically and the wound-healing rates $\left(\mu \mathrm{m}^{2} / \mathrm{h}\right)$ over a $24-\mathrm{h}$ period were then compared in control condition $(-)$, in presence of the TRPC4 inhibitor ML-204 $(100 \mu M,+)(n=8)$ or a combination of ML-204 $(100 \mu \mathrm{M})$ and TRAM-34 $(20 \mu \mathrm{M})(\mathbf{d}, \mathrm{n}=7) .{ }^{*} p<0.05$

physical or functional interactions between other types of $\mathrm{K}^{+}$channels (e.g. BKCa, Kv1.3, hERG, $\mathrm{K}_{\mathrm{ir}} 4.2$ ) and integrins have already been reported in other cell types [30-33]. Levite et al., for example, reported a physical association between Kv1.3 channels and $\beta 1$-integrin, detected by co-immunoprecipitation assays, in human $\mathrm{T}$ cells [32]. The same approach was undertaken in a neuroblastoma cell line to identify a link between hERG1 channel and $\beta 1$-integrin, which were also co-localized [30].

In the present study, we observed a significant increase in $\beta 1$-integrin and $\mathrm{KCa} 3.1$ expression in the membrane fraction of ATII cells cultured on fibronectin coating (Fig. 6c). Although our data did not allow us to define which cellular mechanism could explain this observed up-regulation, it has been proposed in other studies that protein phosphorylation, $\mathrm{Ca}^{2+}$ signalling or $\mathrm{G}$ proteins could be responsible for the modulation of $\mathrm{K}^{+}$channel properties by integrins $[9,58]$. In agreement with our results, it has been also shown that the level of hERG channel co-immunoprecipitated with $\beta 1$-integrin is increased after $\beta 1$-integrin activation [30].

Due to the $\mathrm{Ca}^{2+}$ sensitivity of $\mathrm{KCa} 3.1$ channels, the levels of $\left[\mathrm{Ca}^{2+}\right]_{\mathrm{i}}$ in ATII cells in the absence or presence of a fibronectin matrix were also analyzed. Our data showed that $\left[\mathrm{Ca}^{2+}\right]_{\mathrm{i}}$ is significantly higher in the presence of fibronectin (Fig. 7). This result is in agreement 


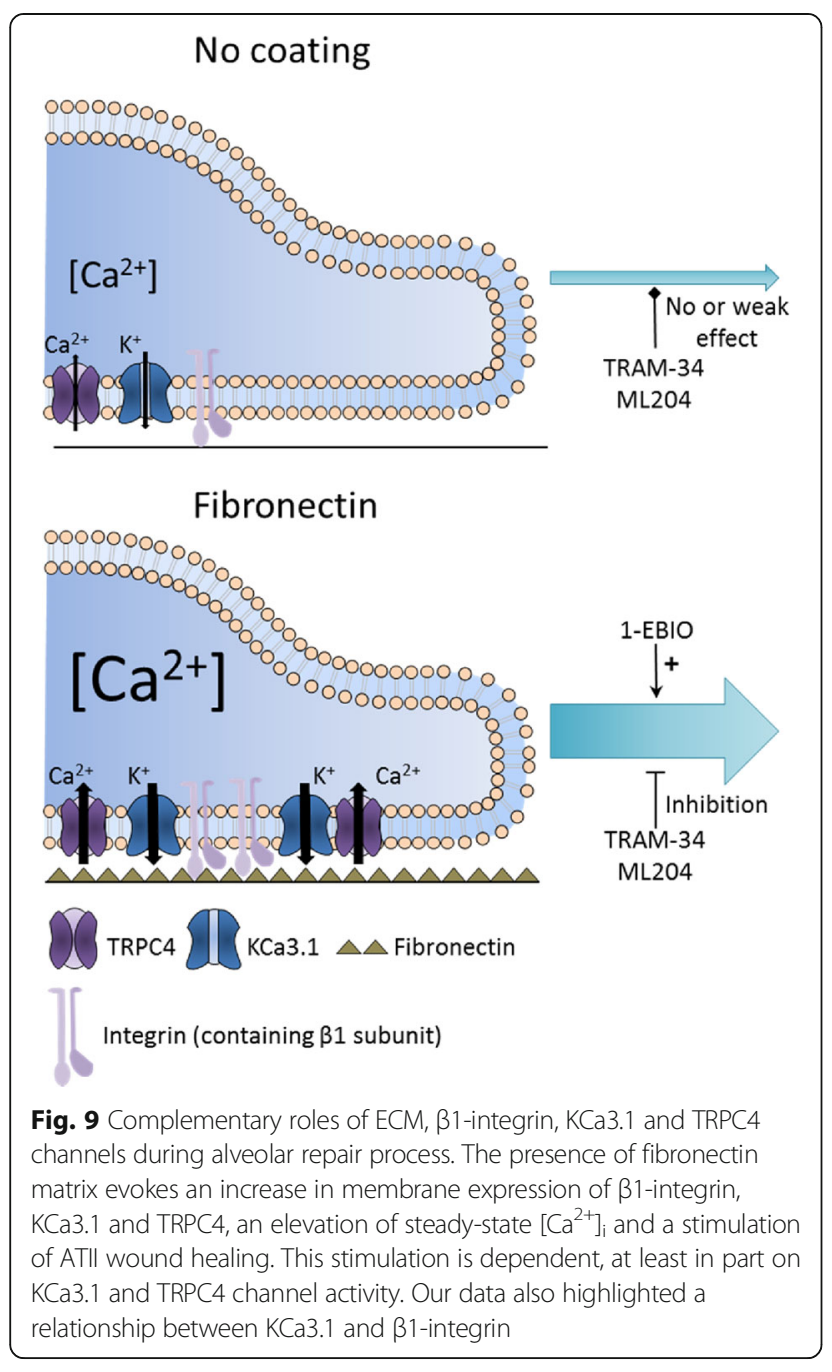

with a study by Sjaastad et al., [59] showing that integrin activation in MDCK cells, using microbeads coated with RGD motif, was associated with $\left[\mathrm{Ca}^{2+}\right]_{\mathrm{i}}$ increase, most probably through a $\mathrm{Ca}^{2+}$ influx. Our Fura-2 assays also indicated that membrane $\mathrm{Ca}^{2+}$ permeability in ATII cells was enhanced in the presence of fibronectin. In an attempt to define the identity of the membrane $\mathrm{Ca}^{2+}$ channel(s) that may be involved in that response, we decided to focus on the TRPC family, because TRPC3 channel has already been shown to facilitate the KCa3.1 channel activation [49]. Although we detected all members of the TRPC family (TRPC1-7, [47], Fig. 8) in ATII cells, only TRPC4 mRNA expression was significantly enhanced in the presence of fibronectin. Moreover, analysis of protein expression in membrane fraction revealed that TRPC4 levels, similarly to $\mathrm{KCa} 3.1$ and $\beta-1$ integrin, were significantly enhanced in ATII cells cultured on fibronectin coating (Fig. 8c). The signalling pathways responsible for TRPC4 up-regulation were not elucidated in our study; however, it has previously been demonstrated that TRPC4 membrane translocation was dependent of Src phosphorylation after EGF stimulation [60]; a phosphorylation pathway also known in the regulation of ion channels by integrin $[9,58]$. The relative contribution of TRPC4, as well as other types of $\mathrm{Ca}^{2+}$ channels, including voltage-dependent and independent $\mathrm{Ca}^{2+}$ channels to the complex $\mathrm{Ca}^{2+}$ signal during wound repair or after changes in integrin and $\mathrm{K}^{+}$channel activation has not been evaluated in that study but would deserve further investigation.

Finally, we observed for the first time that TRPC4 channels are involved in ATII wound healing. In fact, we measured a 3-fold stronger inhibition of ATII wound repair rates with the TRPC4 inhibitor ML204 on the fibronectin matrix than in the absence of coating. This effect is in agreement with the observed increased TRPC expression on fibronectin coating. Although a function of TRPC4 channels in alveolar repair has never been reported before, other members of the TRPC family have already been described as regulators of cell migration in non-tumoural cells (TRPC1 and TRPC3 in intestinal epithelial cells or monocytes respectively [61, 62]) or in lung cancer cells (TRPC1, 3, 4 and 6 [63]). Furthermore, we observed that the combination of KCa3.1 and TRPC4 inhibitors led to an additive inhibitory effect (Fig. 8d), suggesting that these two channels are complementary partners in the control of ATII wound healing on fibronectin.

As described above, our data using KCa3.1 inhibition or silencing demonstrated that KCa3.1 may act as a regulator of the ATII wound-healing repair in vitro. Interestingly, we also showed that the ATII woundhealing rates were improved in the presence of the $\mathrm{KCa}$ activator 1-EBIO (Fig. 5). Based on this evidence, it may be postulated that $\mathrm{KCa} 3.1$ could play an important role in the alveolar epithelial repair after injury and may thus be identified as a potential therapeutic target for alveolar epithelial repair after acute lung injury in vivo. Such a strategy remains to be further investigated, however.

\section{Conclusion}

Our data demonstrate for the first time the complementary roles of fibronectin matrix, $\beta-1$ integrin, $\mathrm{KCa} 3.1$ and TRPC4 channels in the regulation of alveolar epithelial repair processes (Fig. 9). Moreover, our study highlights an improvement in ATII wound-healing after treatment with 1-EBIO, suggesting use of KCa3.1 activators as potential therapeutic strategy to favor the resolution of acute lung injury in vivo.

\section{Competing interests}

The authors declare that they have no competing interests. 


\section{Authors' contributions}

$A G, J C, A P, N T N T$, EM carried out the experiments. AG, JC, AP, NTNT, EM, EB participated to data and statistical analysis. $A G, R G, E B$ conceived and designed the study, they also interpreted that data. AG, JC, RG and EB drafted the manuscript. All authors read and approved the final manuscript.

\section{Acknowledgements}

This work was supported by Canadian Institutes of Health Research (Grant MOP111054), the Natural Sciences and Engineering Research Council of Canada (Grant RGPIN/312177-2011), a scholarship from the Centre de Recherche du Centre Hospitalier de I'Université de Montréal (CRCHUM) and Université de Montréal (E. Brochiero), a fellowship from the Canadian Institutes of Health Research training program of the Respiratory Health Network and Fonds de la Recherche du Québec en Santé (A. Girault), a fellowship of the FRQ-S (A. Girault), a studenship of the Faculté de Médecine, Université de Montréal (J. Chebli). The authors acknowledge logistical assistance from the Research Support Office at the Centre de Recherche du Centre Hospitalier de l'Université de Montréal (CRCHUM) as well as advice from Dr Lise Coderre (for data analysis).

\section{Received: 25 February 2015 Accepted: 21 August 2015} Published online: 04 September 2015

\section{References}

1. Berthiaume $Y$, Lesur $O$, Dagenais A. Treatment of adult respiratory distress syndrome: plea for rescue therapy of the alveolar epithelium. Thorax. 1999;54:150-60.

2. Ware LB, Matthay MA. The acute respiratory distress syndrome. N Engl J Med. 2000;342:1334-49.

3. Shimabukuro DW, Sawa T, Gropper MA. Injury and repair in lung and airways. Crit Care Med. 2003;31:S524-31.

4. Budinger GR, Sznajder Jl. The alveolar-epithelial barrier: a target for potential therapy. Clin Chest Med. 2006;27:655-69.

5. Crosby LM, Waters CM. Epithelial repair mechanisms in the lung. Am J Physiol Lung Cell Mol Physiol. 2010;298:L715-31.

6. lizuka M, Konno S. Wound healing of intestinal epithelial cells. World J Gastroenterol. 2011;17:2161-71.

7. Coraux C, Roux J, Jolly T, Birembaut P. Epithelial cell-extracellular matrix interactions and stem cells in airway epithelial regeneration. Proc Am Thorac Soc. 2008;5:689-94.

8. Sheppard D. Epithelial integrins. Bioessays. 1996;18:655-60.

9. Arcangeli A, Becchetti A. Complex functional interaction between integrin receptors and ion channels. Trends Cell Biol. 2006:16:631-9.

10. Cabodi S, Di Stefano P, Leal MP, Tinnirello A, Bisaro B, Morello V, et al. Integrins and signal transduction. Adv Exp Med Biol. 2010;674:43-54.

11. Herard AL, Pierrot D, Hinnrasky J, Kaplan H, Sheppard D, Puchelle E, et al. Fibronectin and its alpha 5 beta 1-integrin receptor are involved in the wound-repair process of airway epithelium. Am J Physiol. 1996;271:L726-33.

12. Kim HJ, Henke CA, Savik SK, Ingbar DH. Integrin mediation of alveolar epithelial cell migration on fibronectin and type I collagen. Am J Physiol. 1997;273:L134-41.

13. Morales MM, Pires-Neto RC, Inforsato $N$, Lancas T, da Silva LF, Saldiva PH, et al. Small airway remodeling in acute respiratory distress syndrome: a study in autopsy lung tissue. Crit Care. 2011;15:R4.

14. Girault A, Brochiero E. Evidence of K+ channel function in epithelial cell migration, proliferation and repair. Am J Physiol Cell Physiol. 2014;306:C307-19.

15. Trinh NT, Prive A, Kheir L, Bourret JC, Hijazi T, Amraei MG, et al. Involvement of KATP and KVLQT1 K+ channels in EGF-stimulated alveolar epithelial cell repair processes. Am J Physiol Lung Cell Mol Physiol. 2007;293:L870-82.

16. Trinh NT, Prive A, Maille E, Noel J, Brochiero E. EGF and K+ channel activity control normal and cystic fibrosis bronchial epithelia repair. Am J Physiol Lung Cell Mol Physiol. 2008;295:L866-80.

17. Roderick C, Reinach PS, Wang L, Lu L. Modulation of rabbit corneal epithelial cell proliferation by growth factor-regulated $\mathrm{K}(+)$ channel activity. J Membr Biol. 2003;196:41-50.

18. Schwingshackl A, Teng B, Ghosh M, West AN, Makena P, Gorantla V, et al. Regulation and function of the two-pore-domain (K2P) potassium channel Trek-1 in alveolar epithelial cells. Am J Physiol Lung Cell Mol Physiol. 2012;302:L93-L102.
19. Rao JN, Platoshyn O, Li L, Guo X, Golovina VA, Yuan JX, et al. Activation of $\mathrm{K}(+)$ channels and increased migration of differentiated intestinal epithelial cells after wounding. Am J Physiol Cell Physiol. 2002;282:C885-98.

20. Rampino T, Gregorini M, Guidetti C, Broggini M, Marchini S, Bonomi R, et al. KCNA1 and TRPC6 ion channels and NHE1 exchanger operate the biological outcome of HGF/scatter factor in renal tubular cells. Growth Factors. 2007;25:382-91.

21. Wu WK, Li GR, Wong TM, Wang JY, Yu L, Cho CH. Involvement of voltage-gated $\mathrm{K}+$ and $\mathrm{Na}+$ channels in gastric epithelial cell migration. Mol Cell Biochem. 2008:308:219-26.

22. Schwab A, Wojnowski L, Gabriel K, Oberleithner H. Oscillating activity of a $\mathrm{Ca}(2+)$-sensitive $\mathrm{K}+$ channel. A prerequisite for migration of transformed Madin-Darby canine kidney focus cells. J Clin Invest. 1994;93:1631-6.

23. Wang JY, Wang J, Golovina VA, Li L, Platoshyn O, Yuan JX. Role of K(+) channel expression in polyamine-dependent intestinal epithelial cell migration. Am J Physiol Cell Physiol. 2000;278:C303-14.

24. Buchanan PJ, McNally P, Harvey BJ, Urbach V. Lipoxin A4 mediated KATP potassium channel activation results in cystic fibrosis airway epithelial repair. Am J Physiol Lung Cell Mol Physiol. 2013;305:L193-201.

25. Potier M, Tran TA, Chantome A, Girault A, Joulin V, Bougnoux P, et al. Altered SK3/KCa2.3-mediated migration in adenomatous polyposis coli (Apc) mutated mouse colon epithelial cells. Biochem Biophys Res Commun. 2010:397:42-7.

26. Wei JF, Wei L, Zhou X, Lu ZY, Francis K, Hu XY, et al. Formation of Kv2.1-FAK complex as a mechanism of FAK activation, cell polarization and enhanced motility. J Cell Physiol. 2008;217:544-57.

27. Cowley EA, Linsdell P. Characterization of basolateral K+ channels underlying anion secretion in the human airway cell line Calu-3. J Physiol. 2002;538:747-57

28. Mall M, Gonska T, Thomas J, Schreiber R, Seydewitz HH, Kuehr J, et al. Modulation of $\mathrm{Ca} 2+$-activated $\mathrm{Cl}$ - secretion by basolateral $\mathrm{K}+$ channels in human normal and cystic fibrosis airway epithelia. Pediatr Res. 2003;53:608-18.

29. Jin M, Defoe DM, Wondergem R. Hepatocyte growth factor/scatter factor stimulates $\mathrm{Ca} 2+-$ activated membrane $\mathrm{K}+$ current and migration of MDCK II cells. J Membr Biol. 2003;191:77-86.

30. Cherubini A, Hofmann G, Pillozzi S, Guasti L, Crociani O, Cilia E, et al. Human ether-a-go-go-related gene 1 channels are physically linked to beta1 integrins and modulate adhesion-dependent signaling. Mol Biol Cell. 2005;16:2972-83.

31. deHart GW, Jin T, McCloskey DE, Pegg AE, Sheppard D. The alphagbeta1 integrin enhances cell migration by polyamine-mediated modulation of an inward-rectifier potassium channel. Proc Natl Acad Sci U S A. 2008;105:7188-93.

32. Levite M, Cahalon L, Peretz A, Hershkoviz R, Sobko A, Ariel A, et al. Extracellular $\mathrm{K}(+)$ and opening of voltage-gated potassium channels activate $T$ cell integrin function: physical and functional association between Kv1.3 channels and beta1 integrins. J Exp Med. 2000;191:1167-76.

33. Yang $Y$, Wu $X$, Gui $P$, Wu J, Sheng JZ, Ling $S$, et al. Alpha5beta1 integrin engagement increases large conductance, $\mathrm{Ca} 2+$-activated $\mathrm{K}+$ channel current and Ca2+ sensitivity through c-src-mediated channel phosphorylation. J Biol Chem. 2010;285:131-41.

34. Leroy C, Dagenais A, Berthiaume Y, Brochiero E. Molecular identity and function in transepithelial transport of K(ATP) channels in alveolar epithelial cells. Am J Physiol Lung Cell Mol Physiol. 2004;286:L1027-37.

35. Leroy C, Prive A, Bourret JC, Berthiaume Y, Ferraro P, Brochiero E. Regulation of ENaC and CFTR expression with $\mathrm{K}+$ channel modulators and effect on fluid absorption across alveolar epithelial cells. Am J Physiol Lung Cell Mol Physiol. 2006;291:L1207-19.

36. Bardou O, Prive A, Migneault F, Roy-Camille K, Dagenais A, Berthiaume Y, et al. $\mathrm{K}(+)$ channels regulate $\mathrm{ENaC}$ expression via changes in promoter activity and control fluid clearance in alveolar epithelial cells. Biochim Biophys Acta. 1818:2012:1682-90.

37. Dobbs LG, Gonzalez R, Williams MC. An improved method for isolating type II cells in high yield and purity. Am Rev Respir Dis. 1986;134:141-5.

38. Brochiero E, Dagenais A, Prive A, Berthiaume Y, Grygorczyk R. Evidence of a functional CFTR Cl(-) channel in adult alveolar epithelial cells. Am J Physio Lung Cell Mol Physiol. 2004;287:L382-92.

39. Girault A, Prive A, Trinh NT, Bardou O, Ferraro $P$, Joubert $P$, et al. Identification of KvLQT1 K+ channels as new regulators of non-small cell lung cancer cell proliferation and migration. Int J Oncol. 2014;44:838-48.

40. Maille E, Trinh NT, Prive A, Bilodeau C, Bissonnette E, Grandvaux N, et al. Regulation of normal and cystic fibrosis airway epithelial repair processes by TNF-alpha after injury. Am J Physiol Lung Cell Mol Physiol. 2011;301:L945-55. 
41. Trinh NT, Bardou O, Prive A, Maille E, Adam D, Lingée S, et al. Improvement of defective cystic fibrosis airway epithelial wound repair after CFTR rescue. Eur Respir J. 2012;40:1390-400.

42. Bilodeau C, Bardou O, Maille E, Berthiaume Y, Brochiero E. Deleterious impact of hyperglycemia on cystic fibrosis airway ion transport and epithelial repair. J Cyst Fibros. 2015

43. Klein H, Garneau L, Trinh NT, Prive A, Dionne F, Goupil E, et al. Inhibition of the KCa3.1 channels by AMP-activated protein kinase in human airway epithelial cells. Am J Physiol Cell Physiol. 2009;296:C285-95.

44. Dagenais A, Frechette R, Clermont ME, Masse C, Prive A, Brochiero E, et al. Dexamethasone inhibits the action of TNF on $\mathrm{ENaC}$ expression and activity. Am J Physiol Lung Cell Mol Physiol. 2006;291:L1220-31.

45. Grynkiewicz G, Poenie M, Tsien RY. A new generation of Ca2+ indicators with greatly improved fluorescence properties. J Biol Chem. 1985;260:3440-50.

46. Wei AD, Gutman GA, Aldrich R, Chandy KG, Grissmer S, Wulff H. International Union of Pharmacology. LII. Nomenclature and molecular relationships of calcium-activated potassium channels. Pharmacol Rev. 2005;57:463-72.

47. Venkatachalam K, Montell C. TRP channels. Annu Rev Biochem. 2007:76:387-417.

48. Nilius B, Szallasi A. Transient receptor potential channels as drug targets: from the science of basic research to the art of medicine. Pharmacol Rev. 2014;66:676-814

49. Senadheera S, Kim Y, Grayson TH, Toemoe S, Kochukov MY, Abramowitz J, et al. Transient receptor potential canonical type 3 channels facilitate endothelium-derived hyperpolarization-mediated resistance artery vasodilator activity. Cardiovasc Res. 2012;95:439-47.

50. Miller M, Shi J, Zhu Y, Kustov M, Tian JB, Stevens A, et al. Identification of ML204, a novel potent antagonist that selectively modulates native TRPC4/ C5 ion channels. J Biol Chem. 2011;286:33436-46.

51. Nishida T, Nakagawa S, Awata T, Ohashi Y, Watanabe K, Manabe R. Fibronectin promotes epithelial migration of cultured rabbit cornea in situ. J Cell Biol. 1983:97:1653-7.

52. Cruse G, Singh SR, Duffy SM, Doe C, Saunders R, Brightling CE, et al. Functional KCa3.1 K+ channels are required for human fibrocyte migration. J Allergy Clin Immunol. 2011;128:1303-9.

53. Schwab A, Schuricht B, Seeger P, Reinhardt J, Dartsch PC. Migration of transformed renal epithelial cells is regulated by $\mathrm{K}+$ channel modulation of actin cytoskeleton and cell volume. Pflugers Arch. 1999:438:330-7.

54. Chimote AA, Hajdu P, Kucher V, Boiko N, Kuras Z, Szilagyi O, et al. Selective inhibition of KCa3.1 channels mediates adenosine regulation of the motility of human T cells. J Immunol. 2013;191:6273-80.

55. D'Alessandro G, Catalano M, Sciaccaluga M, Chece G, Cipriani R, Rosito M, et al. KCa3.1 channels are involved in the infiltrative behavior of glioblastoma in vivo. Cell Death Dis. 2013;4:e773.

56. Grossinger EM, Weiss L, Zierler S, Rebhandl S, Krenn PW, Hinterseer E, et al. Targeting proliferation of chronic lymphocytic leukemia (CLL) cells through KCa3.1 blockade. Leukemia. 2014:28:954-8

57. Tao R, Lau CP, Tse HF, Li GR. Regulation of cell proliferation by intermediateconductance $\mathrm{Ca} 2+-$ activated potassium and volume-sensitive chloride channels in mouse mesenchymal stem cells. Am J Physiol Cell Physiol. 2008;295:C1409-16.

58. Davis MJ, Wu X, Nurkiewicz TR, Kawasaki J, Gui P, Hill MA, et al. Regulation of ion channels by integrins. Cell Biochem Biophys. 2002;36:41-66.

59. Sjaastad MD, Lewis RS, Nelson WJ. Mechanisms of integrin-mediated calcium signaling in MDCK cells: regulation of adhesion by IP3- and store-independent calcium influx. Mol Biol Cell. 1996;7:1025-41.

60. Odell AF, Scott $J L$, Van Helden DF. Epidermal growth factor induces tyrosine phosphorylation, membrane insertion, and activation of transient receptor potential channel 4. J Biol Chem. 2005;280:37974-87.

61. Rao JN, Platoshyn O, Golovina VA, Liu L, Zou T, Marasa BS, et al. TRPC functions as a store-operated Ca2+ channel in intestinal epithelial cells and regulates early mucosal restitution after wounding. Am J Physiol Gastrointest Liver Physiol. 2006:290:G782-92.

62. Zhao Z, Ni Y, Chen J, Zhong J, Yu H, Xu X, et al. Increased migration of monocytes in essential hypertension is associated with increased transient receptor potential channel canonical type 3 channels. PLoS One. 2012;7:e32628.

63. Jiang HN, Zeng B, Zhang Y, Daskoulidou N, Fan H, Qu JM, et al. Involvement of TRPC channels in lung cancer cell differentiation and the correlation analysis in human non-small cell lung cancer. PLoS One. 2013:8:e67637.

\section{Submit your next manuscript to BioMed Central and take full advantage of:}

- Convenient online submission

- Thorough peer review

- No space constraints or color figure charges

- Immediate publication on acceptance

- Inclusion in PubMed, CAS, Scopus and Google Scholar

- Research which is freely available for redistribution

Submit your manuscript at www.biomedcentral.com/submit 